\title{
PENERAPAN QUALITY CONTROL DI LAUNDRY HOTEL BASKO PADANG
}

\author{
Desi Ratna sari ${ }^{1}$, Kasmita ${ }^{2}$, Hijriyantomi Suyuthie ${ }^{3}$ \\ Program Studi D4 Manajemen Perhotelan \\ -Jurusan Pariwisata \\ FPP Universitas Negeri Padang \\ Email: Ratnadesi16@gmail.com
}

\begin{abstract}
Penelitian ini bertujuan untuk mengetahui Penerapan Quality Control Di Laundry Hotel Basko Padang. Penelitian ini terdiri dari lima Indikator dari lima indikator itu hanya 1 yang di teliliti dari lima indikator tersebut. Dari lima indikator itu hanya Proses kerja di laundry Hotel Basko Padang saja yang di teliti. Jenis penelitian ini adalah penelitian deskriptif dengan pendekatan data kualitatif. Penentuan informan peneliti dengan purposive sampling yaitu 1 orang Manager Laundry, 1 orang Supervisor Laundry, 2 orang karyawan operasional Laundry Hotel. Pengumpulan data melalui wawancara,observasi, dan dokumentasi. Teknik analisis data yang di gunakan yaitu dengan dengan cara reduksi data, penyajian data dan kesimpulan. Berdasarkan hasil peneliti secara umum penerapan Quality Control Di Laundry Hotel Basko Padang yang di lihat dari Proses Laundry berupa: Taking Order yang di lakukan oleh Order Taker maupun dari karyawan Laundry itu sendiri, Pengambilan Pakain (picking-up), Pengecekkan dan Pemberian Identitas (cheking dan marking), Pencucian (washing), Pemerasan (extracting), Proses Pengeringan (drying), Proses Penyetrikaan (Pressing), Pengepakan (parking/finishing), Pengantaran (Delivering).
\end{abstract}

Kata Kunci: Penerapan Quality Control Di Laundry Hotel Basko Padang

${ }^{1}$ Prodi D4 Manajemen Perhotelan untuk Wisuda periode Desember $2018^{2}$ Dosen Jurusan Pariwisata FPP-UNP 


\section{Pendahuluan}

Banyaknya minat para pengusaha menimbulkan persaingan yang sangat ketat pada industri perhotelan. Hal ini menuntut para pengusaha harus lebih kreatif dalam memilih konsep hotel. Para pengusaha harus mengetahui selera dari konsumen. Banyak hal yang biasanya menjadi pertimbangan konsumen dalam memilihi hotel saat hendak menginap baik itu dari produk maupun jasa yang ditawarkan oleh setiap hotel. Adanya pertimbangan konsumen dalam memilih hotel, maka pihak hotel juga harus menawarkan hal-hal yang menarik konsumen untuk menginap seperti fasilitas yang memadai dan kualitas pelayanan yang baik. Fasilitas yang memadai dan kualitas pelayanan yang baik akan memberikan kepuasan serta harapan tamu dapat terpenuhi, bahkan mungkin bisa melampaui harapan dari tamu.

Hotel merupakan salah satu akomodasi penginapan untuk wisatawan dalam negeri maupun luar negeri, yang menyediakan makanan, minuman, dan hal lain sebagai penunjang. Hotel menurut Keputusan Menteri Pariwisata, Pos dan telekomunikasi No. KM. 37/PW. 304/ MPPT. 1986 adalah "Suatu jenis akomodasi yang mempergunakan sebagian atau seluruh bangunan untuk menyediakan jasa penginapan, makanan, dan minuman, serta penunjang lainnya sebagai umum yang dikelola secara komersial”.

Hotel Basko memberikan fasilitas dan kenyamanan kepada tamu. Fasilitas dan kenyamanan yang diberikan oleh pihak Hotel Basko akan membuat rasa puas dan nyaman bagi setiap tamu yang menginap. Hotel Basko mempunyai beberapa departemen, setiap departemen bertanggung jawab atas kepuasan tamu yang menginap. Adapun departemen itu adalah Front Office Department, Housekeeping Department, Food And Beverage Department, Accounting Department, Engeneering Department, Sales And Marketing Department, Human Resources Department. Dalam penelitian ini penulis akan membahas tentang Housekeeping department yang merupakan salah satu departemen yang sangat berperan penting untuk kepuasan tamu. Departemen Housekeeping bertanggung jawab terhadap kebersihan pada hotel baik di kamar maupun di area-area tertentu. Pengertian umum menurut Sugiarto dan Sulartiningrum, (2003: 23) "Housekeeping adalah salah satu bagian yang ada di dalam hotel yang menangani hal-hal terkait dengan keindahan, kerapian, kebersihan, kelengkapan seluruh kamar juga seluruh areal umum lainnya agar seluruh tamu dan karyawan dapat merasa aman dan nyaman di dalam hotel". 
Hal ini tentu mengharuskan para Manager Laundry, Supervisor Laundry melakukan Quality Control terhadap semua pakaian tamu, pentingnya Quality Control di lakukan adalah untuk menghasilkan produk yang baik melalui proses yang baik juga. Dengan proses dan Quality Control yang di lakukan agar produk dan jasa yang di hasilkan tidak mengecewakan tamu maupun konsumen. Salah satu yang memegang peranan penting dalam menghasilkan Produk yang baik maka dari itu Quality Control penting di lakukan dalam suatu usaha, agar suatu usaha itu berjalan dengan baik tanpa ada komplain dari tamu untuk selanjutnya.

Pentingnya Quality Control dilakukan adalah untuk menghasilkan suatu produk yang baik, yang dilakukan dengan proses kerja yang sesuai dengan ketetapan prosedur kerja laundry yang telah ditetapkan oleh pihak Hotel. Quality Control harus di lakukan oleh supervisor Laundry agar tidak terjadinya kesalahan yang sama atau pun komplain dari tamu. Hasil yang dicapai oleh laundry section dari sebuah hotel akan tergantung pada tenaga kerja yang dimiliki. Berdasarkan undang-undang ketenagakerjaan pasal 1 ayat 2 tenaga kerja adalah setiap orang yang mampu melakukan pekerjaan guna menghasilkan barang atau jasa baik untuk memenuhi kebutuhan sendiri maupun untuk masyarakat. Semakin baik kinerja yang ditunjukan oleh tenaga kerja, akan semakin baik hasil yang diperoleh oleh bagian laundry. Guna menghasilkan kualitas pelayanan yang baik, sumber daya manusia (SDM) hotel harus diperhatikan. SDM merupakan objek yang penting dalam sebuah operational. Operational hotel akan berjalan sangat baik apabila memiliki SDM yang berkualitas di bidangnya dan SDM tersebut dapat bekerja dengan efektif dan memiliki motivasi kerja yang baik.

Berdasarkan masalah yang telah di temukan dari komplain para tamu yaitu, seperti masalah yang pernah terjadi pada tanggal 4 juli 2017 proses pencucian yang dilakukan oleh karyawan laundry yaitu robeknya baju tamu pada saat melakukan proses laundry, kelalaian karyawan laundry yang tidak memisahkan baju putih dengan baju berwarna hingga terjadinya kelunturan pada baju putih, dan kancing baju yang lepas saat proses pencucian. Selain dari masalah di atas ada juga masalah yang terjadi pada saat valet atau karyawan laundry yang bertanggung jawab terhadap pengambilan dan pengembalian pakaian tamu ke kamar-kamar tamu. Terlambatnya pengambilan (pick-up) pakaian tamu yang akan di laundry oleh valet. Padahal tamu telah menginformasikan kepada Laundry Section melalui telepon, bahkan 
sampai tamu menelpon lagi untuk

\section{Metodologi penelitian}

Jenis penelitian adalah penelitian deskriptif dengan pendekatan datakualitatif. Waktu dan tempat penelitian ini adalah tanggal 18 Desember - 25 Desember 2017. Informan penelitian pada tempat penelitian ini dilakukan secara purposive sampling yaitu 4 orang, yang terdiri dari Manager Laundry, Supervisor Laundry, Karyawan Operasional Laundry Hotel.

\section{Hasil Penelitian Dan Pembahasan}

\section{Hasil Penelitian}

Setelah dilakukan wawancara, observasi dan dokumentasi, maka hasil dari penelitian Penerapan Quality Control Di Laundry Hotel Basko Padang sebagai berikut:

\section{a. Memberikan Informasi (Taking Order)}

Berdasarkan hasil wawancara, observasi dan dokumentasi, perihal Taking Order dapat di simpulkan bahwa pada proses taking order karyawan Laundry Hotel Basko Padang sudah melakukan dengan baik sesuai dengan peraturan yang di tetapkan oleh Hotel.

\section{b. Menganbil Pakaian (Pick-Up) \\ Berdasarkan hasil wawancara, observasi dan}

kedua dan ketiga kalinya.

Jenis data dalam penelitian adalah data primer dan data skunder. Data primer dalam penelitian ini adalah data hasil wawancara, observasi, dan dokumentasi yang di dapat dariinforman peneliti ini adalah proses kerja laundry dan Quality Control yang di lakukan di Laundry Hotel Basko Padang. Teknik analisis data kualitatatif meliputi tiga alur kegiatan yakni reduksi data, penyajian data dan pengambilan keputusan.

dokumentasi, mengenai
proses pick-up dapat
disimpulkan bahwa pada
proses picking-up masih
adanya karyawan laundry
yang tidak melakukan proses
picking-up secara baik.

c. Pengecekkan dan pemberian identitas (Checking dan Marking) Berdasarkan hasil wawancara, observasi dan dokumentasi, mengenai proses Checking dan Marking dapat disimpulkan bahwa pada proses checking dan marking masih terdapat 2 orang karyawan laundry yang tidak melakukan prosedur checking dan marking secara benar.

\section{d. Pencucian (Washing)}

Berdasarkan hasil wawancara, observasi dan dokumentasi, mengenai 
proses washing dapat di simpulkan bahwa pada proses washing terdapat satu orang dari tujuh orang karyawan laundry yang tidak melakukan prosedur washing secara baik setelah melalui proses Quality Control dari supevisor.

e. Pemerasan (Extracting)

Berdasarkan hasil wawancara, observasi dan dokumentasi, mengenai proses extracting dapat disimpulkan bahwa pada proses extracting, karyawan laundry telah melakukan prosedur extracting secara baik.

\section{f. pengeringan (Drying)}

Berdasarkan hasil wawancara, observasi dan dokumentasi, mengenai proses drying dapat disimpulkan bahwa pada proses drying masih adanya karyawan laundry yang tidak melakukan prosedur drying secara baik dan tidak benar.

\section{g. Proses penyetrikaan (Pressing)}

\section{Pembahasan}

Penelitian ini telah menemukan gambaran mengenai Penerapan Quality Control Di Laundry Hotel Basko Padang. Berdasarkan analisis data yang dijabarkan perindikator dapat dilihat secara umum bahwa Penerapan Quality Control Di Laundry yang

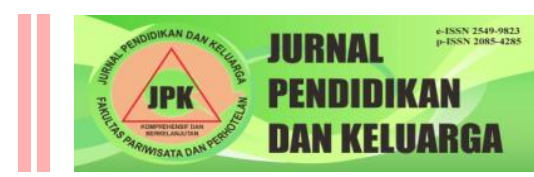

Berdasarkan hasil wawancara, observasi dan dokumentasi, mengenai proses pressing dapat disimpulkan bahwa pada proses pressing terdapat dua orang karyawan laundry yang tidak melakukan prosedur pressing secara baik.

\section{h. Pengepakan (Packing)}

Berdasarkan hasil wawancara, observasi dan dokumentasi, mengenai proses packing dapat disimpulkan bahwa proses packing ternyata seluruh karyawan laundry telah melakukan prosedur packing secara baik.

\section{i. Pengantaran \\ (Delivering)}

Berdasarkan hasil

wawancara, observasi dan dokumentasi, mengenai proses delivering dapat disimpulkan bahwa proses delivering ternyata seluruh karyawan laundry telah melakukan proses delivery secara baik.

dilihat dari 9 proses yang di lalui setiap tahap, mulai dari Taking Order, Pick-up, Cheking and Marking, Washing, Extracting, Drying, Pressing, Packing, dan Delivering. Dalam hal ini dapat kita lihat bahwa masih ada karyawan Laundry Hotel Basko Padang yang masih belum melakukan proses 
Laundry secara banar, tapi sebagian dari itu sudah di lalui dengan proses yang baik. Maka dari itu Manager Laundry dan Supervisor harus lebih sering melakukan Quality Control

\section{Kesimpulan Dan Saran}

\section{Kesimpulan}

Secara keseluruhan

Penerapan Quality Control Di Laundry Hotel Basko Padang yang di tinjau dari proses kerja Laundry sudah cukup baik tetapi masih ada yang belum diterapkan oleh beberapa karyawan Laundry Hotel Basko

\section{Saran}

Pihak Hotel lebih baik menerapkan semua standar proses Laundry yang sesuai dengan kebijakan yang telah di tentukan oleh pihak Hotel, agar usaha Laundry lebih berkembang dan tamu yang ingin melaundrykan pakianya percaya terhadap Laundry Hotel Basko Padang.

\section{DAFTAR PUSTAKA}

Ishikawa, Koaru. 2008. Pengaruh

TMQ terhadap Kinerja

karyawan. Bandung: PT

rosdakarya.

Keputusan Menteri Pariwisata, Pos dan telekomunikasi No. KM. 37/PW. 340/MPPT. 2000. terhadap hasil kerja karyawan Laundry yang dikerjakan, agar tidak terjadinya komplain untuk tamu yang selanjutnya.

Padang, Quality Control yang dilakukan oleh SPV Laundry Hotel Basko Padang terhadap karyawannya. Sehingga pelayanan yang diberikan oleh karyawan laundry masih kurang cepat, sehingga membutuhkan waktu yang cukup lama.

Disarankan agar penelitian ini menjadi bahan untuk menambah wawasan dan ilmu pengetahuan, serta menjadi informasi yang memadai khususnya bagi pihak terkait dan menjadi bahan pembelajaran. Dan kepada para peneliti lain yang ingin melakukan penelitian lebih lanjut sebaiknya meneliti Quality Contral yang di tinjau dari produk.

Noaman, Selrif. 2007. Laundry Manual. New York: Mc. Graw-Hill Companies. Inc

Pfleger, dkk. 2000. Manajemen Tata Graha. Jakarta: Bumi Aksara.

Rumekso. 2002 Housekeeping Hotel. Yogyakarta: Andi

SK Menteri Perhubungan No. 241/II/2005.

Sugiyono. 2013. Metode Penelitian Kuantitatif, Kualitatif, dan $R \& D$. Bandung: Alfabeta. 
Utari, Devi rahmi. 2013.

PENGARUH TOTAL

QUALITY MANAGEMENT

DAN PENGENDALIAN

PERSONAL TERHADAP
KINERJA MANAJERIAL.

Padang: FE UNP. 